\title{
Spatial Price Dynamics and Asymmetric Price Transmission in Skim Milk Powder International Trade: Evidence from Export Prices for New Zealand and Ireland
}

\author{
Huidan Xue ${ }^{1, *}$, Chenguang $\mathrm{Li}^{2}$ and Liming Wang ${ }^{1,3}$ \\ 1 School of Economics and Management, Beijing University of Technology, Beijing 100124, China; \\ liming.wang@ucd.ie \\ 2 School of Agriculture and Food Science, University College Dublin, Belfield, Dublin 4, Ireland; \\ chenguang.li@ucd.ie \\ 3 Irish Institute for Chinese Studies, University College Dublin, Belfield, Dublin 4, Ireland \\ * Correspondence: huidan.xue@ucdconnect.ie
}

\section{check for}

updates

Citation: Xue, H.; Li, C.; Wang, L. Spatial Price Dynamics and Asymmetric Price Transmission in Skim Milk Powder International Trade: Evidence from Export Prices for New Zealand and Ireland. Agriculture 2021, 11, 860. https:// doi.org/10.3390/agriculture11090860

Academic Editors: David Barling, Antonella Samoggia, Guðrún Ólafsdóttir and Sanzidur Rahman

Received: 25 June 2021

Accepted: 2 September 2021

Published: 8 September 2021

Publisher's Note: MDPI stays neutral with regard to jurisdictional claims in published maps and institutional affiliations.

Copyright: (c) 2021 by the authors. Licensee MDPI, Basel, Switzerland. This article is an open access article distributed under the terms and conditions of the Creative Commons Attribution (CC BY) license (https:/ / creativecommons.org/licenses/by/ $4.0 /)$.

\begin{abstract}
A fast-changing global landscape highlights the importance of understanding spatial price dynamics in key international markets such as China, especially in the era of COVID-19 pandemic with international food trade and food system experiencing an unprecedented challenge. Nowadays, New Zealand's dominant position in China's dairy import market is being challenged by European Union (EU) dairy exporters leading to intensified market competition. Using monthly export data of skim milk powder (SMP), we applied threshold cointegration models along with asymmetric error correction models to examine spatial price dynamics and price transmissions of New Zealand and Ireland in Chinese and global markets. We found that New Zealand's export prices retain their leadership position in China, Ireland's export prices are well more aligned with those in international markets. In terms of own-country price transmission, Ireland's relatively symmetric and swift adjustments were found to contrast with New Zealand's SMP export prices, which displayed more asymmetric price transmissions.
\end{abstract}

Keywords: threshold cointegration; asymmetric price transmission; skim milk powder; volatility

\section{Introduction}

In recent years, policy changes and market volatility in dairy markets in the European Union (EU) including the termination of the EU milk quota, the Russian ban on EU dairy products, Brexit, Euro exchange rate fluctuations and so on, have brought greater challenges, as well as incentives, for EU policymakers and dairy exporters to expand in international markets [1,2]. Meanwhile, China has increasingly become a key international market destination for dairy exporters across the globe, attributing to its rising demand for dairy products, the embracing of westernized food consumption patterns, and consumers' trust issues with domestic dairy safety, etc. [3-8]. As a result, the past five years has seen rapid expansion by major EU dairy exporting countries to the Chinese market. For example, Denmark and the Netherlands experienced 133\% and 26\% increases, respectively, in the export of condensed milk to China. The intensification of the trade facilitation strategies is expected to stimulate price transmission and market integrations. While at the same time, Irish dairy exports face uncertainties with new opportunities and challenges due to Brexit and dairy quota abolition: (1) possible Non-Tariff Barriers to trade (NTBs) and market loss in the UK; (2) the increasing of milk production and an intensive milk powder investment would cause a surplus that needs to be exported to new markets. In the near future, the Chinese market for SMP will become more important and competitive with anticipation of SMP market integration that will be determined by several factors. Firstly, deepening and the ongoing bilateral and multilateral trade agreements such as the updated China-New Zealand Free Trade Agreement and Regional Comprehensive 
Economic Partnership (RCEP), will strengthen the international trade with China in AsiaPacific Region. Secondly, the efforts of major SMP importers, such as China, to boost their domestic dairy industry and build up consumer confidence in domestic milk powder products will intensify competition in the Chinese market. Thirdly, predictable and strategic market extensions for EU dairy exporters after the abolition of milk production quotas will make EU dairy exporting countries try harder to find new markets. For example, Ireland has turned its focus on the Chinese market and is trying to establish an Irish dairy products image under Origin Green (e.g., healthy, "green", sustainable inherent to the Irish dairy sector) to Chinese consumers who have an increasing demand for dairy food but are still affected by the trauma of domestic milk powder safety disasters thereby looking towards imports of premium milk powder products [1].

However, competing for the Chinese market is no easy task for EU dairy exporters facing strong competition from other international players. In particular, New Zealand, a major dairy exporter in the Southern Hemisphere, has been a dominant player in China's dairy market, accounting for $57.3 \%$ of its total dairy imports, thanks to its strong export orientation, close geographic proximity, and free-trade agreement with the Chinese government [9] (Data source: OEC. Authors calculated by aggregating products catagorized as HS Code: 0401, 0402, 0403, 0404, 0405 and 0406). In increasingly integrated global markets and intensified market competition has heightened price volatility, causing further risks for the dairy industry [10]. Thus, to dairy exporters, policymakers and economists, a better understanding of the price dynamics and linkages among geographically separated markets (aka, spatial price transmission) are of crucial importance to facilitate trade policymaking, investment decisions, and export management.

Spatial price dynamics and transmission of food commodities have been extensively explored in the literature over the years. According to the Law of One Price (LOP), the price for commodities in inefficient and undistorted international trade markets acts as a primary mechanism linking various regions, subject to costs associated with space, time and various marketing activities [11,12]. In reality, LOP may no longer hold due to the presence of various factors (such as transaction costs, trade policies, and market power) that constrain the pass-through of price signals from one market to another (see [13] for a comprehensive review on this topic). Therefore, different econometric models have been developed and applied to study asymmetric spatial price transmissions and explore market integrations and price dynamics. Despite the literature available on spatial price transmission, more current studies that incorporate the increasing scale of international market integration and capture changing price dynamics for key export commodities in specific markets are much needed. In particular, there has been no empirical study that explicitly explores the asymmetries in price transmission between two competitors in a specific market such as the Chinese market. The proposed study aims to address this gap in the literature.

The objective of the paper was to investigate spatial price transmissions relevant to international dairy competitors in China, to decipher underlining dynamics and potential interactions of price movements. Given New Zealand's dominant position and the changing market landscape following the rapid growth of imports from EU dairy exporters, we focused our investigation on the price dynamics between the dominant player (New Zealand) and a new player to identify price leadership. Ireland was chosen as the representative new market entrant in this study, because: (1) the Irish dairy industry is highly export-oriented (with more than $80 \%$ of its dairy products exported and consumed overseas every year) and faces challenges to explore new export destinations besides the UK to tackle challenges raised by Brexit; (2) its territory and population sizes and geographic feature are similar to New Zealand. To some extent, New Zealand and Ireland share similar natural endowments for dairy but with distinctive operations and trade patterns; and (3) China has become its second-largest export market since 2014 as well as an important target market $[1,14]$ Irish dairy industry has increasing interests and efforts to expanding its market share in the Chinese market; (4) Major EU dairy exporting countries have been trying hard to expand its market share in the Chinese market, Ireland can be 
as a case to study and conclusions drawn from Ireland can give valuable implications for other EU dairy exporting countries. The study also examined asymmetry in export prices transmission for New Zealand and Ireland in international and in Chinese markets, to identify the level of market integration and the importance of the Chinese market. The empirical analysis of price dynamics provides insights and policy implications for other European and international dairy exporters facing similar situations.

Among various dairy products, SMP is chosen as the product to investigate in this study for the following reasons: (a) The vital export position of SMP in the world: SMP has remained the third largest internationally traded dairy commodity (after whole milk powder and cheese) in recent years, in terms of trade weight [15] It is a vital commodity besides butter that is sustained by stocks and intervention price policies by major dairy exporters such as the EU and the United States (US). Substantial amounts have been invested by the European dairy sector in powder drying facilities for export markets, and SMP production is expected to reach 1.6 million tonnes in 2024, driven by strong global demand [2] In addition, current heightened trade frictions between the US and China may lead to more opportunities for EU exporters in the Chinese market. (b) China is heavily dependent on imported SMP and is a key importer of SMP. (See Section 2 for more details on this). (c) In principle, the price dynamics of SMP among different exporters can be linked to each other because of market integration and a substitution effect between two homogenous products and SMP is relatively homogenous compared with other dairy products [16,17].

The rest of the paper is organized as follows. Section 2 provides details of China's SMP imports, with a special focus on the export situation of New Zealand and Ireland. Section 3 presents the methodology and the empirical models for spatial price relationships. Section 4 reports the empirical results for own-country price relationships. Section 5 presents empirical results of the cross-country price relationship in the Chinese Market. Section 6 presents discussions for this study. Lastly, Section 7 sets out the conclusions of the study.

\section{Import SMP Market in China}

In this section, we provide an overview of China's SMP market and its potential growth. We also explain the growth and development of SMP exports from New Zealand and Ireland in recent years, with a special focus on expansion in the Chinese market.

China is a key importer of several dairy products and has become a competitive arena for major dairy exporters, especially for SMP. In 2018, the imported skim milk powder accounted for approximately $93.34 \%$, while the domestic production accounted for only 6.66\% (Data from OECD-FAO Agricultural Outlook 2019-2028).

The future perspective of China's SMP imports is promising for the following reasons: (a) The Chinese government has been promoting the consumption of milk to enhance citizen's nutrition for many years and Chinese citizens have been changing their diet habits. The main consumer groups for milk powder in China (children and senior citizens in urban areas) have been growing. The population group aged between $0-14$ has increased by $2.05 \%$ between 2010 and 2015, and the population group aged over 65 has increased by $38.54 \%$ between 2006 and 2015 (Data estimated by using data from National Bureau of Statistics of China). (b) The increase in milk demand is greater than the growth of domestic milk production [18]. As China's national statistics illustrate, milk production has increased by $17.58 \%$, while the urban population increased by $32.30 \%$ between 2006 and 2015. (c) E-commerce platforms in China such as Alibaba, Tmall and JD with overseas shopping channels have facilitated a change in the shopping habits among Chinese consumers and enable households in every part of China to buy imported products online, which has greatly boosted foreign milk powder imports [8,19], and (d) Shattered consumer confidence following severe food safety incidents (such as the 2008 milk scandal incident) has resulted in a tendency for Chinese consumers (especially urban consumers) to prefer imported products $[8,20,21]$. 
New Zealand is the dominant player in the Chinese SMP market accounting for 57.3\% of China's total dairy import [9]. The dairy sector has been the largest goods export sector in New Zealand and has been on an upward trend over the past two decades [22] and the 2008 bilateral China-New Zealand Free Trade Agreement (FTA) gradually reduces tariffs on dairy products to zero with milk powders phased out by 2019. Favourable trade policies, ongoing development of a global network by the New Zealand Dairy Board, and Fonterra subsidiaries overseas make the dairy sector more competitive in its export markets [23]. Chinese SMP imports from New Zealand have grown rapidly since 2008, reaching a peak in 2014, following which the level of imports dropped, mainly due to high SMP stocks in China.

Compared to New Zealand, Ireland is a much smaller player in the Chinese SMP market. The market share of Irish SMP in the Chinese market accounts for $2.26 \%$ of China's total SMP imports by value in 2016 (Estimated by using the data from UN Comtrade). As a member of the European Union having access to the corresponding favourable trade policies, traditionally Irish dairy export commodities were mainly destined for the UK and other European markets. In 2016, Ireland's SMP value of exports to China only accounted for $5.72 \%$ of its total exports. However, with the abolition of EU milk quotas in 2016, Ireland is expected to see a $50 \%$ milk production increase by 2020. Meanwhile, Brexit imposes a great level of uncertainty and risk in the UK market. As an export-oriented country with more than $80 \%$ of its dairy products exported overseas, rapid expansion to alternative international market destinations is crucial to the Irish dairy industry. Under such a situation, China has become an increasingly important strategic market for Ireland with fast growth in market share since 2012 [1,14].

Nowadays, New Zealand's dominant position in China's dairy import market is likely to be challenged by dairy exporters from the EU through intensified market competition. The fast-changing international landscape has demanded a better understanding of spatial price dynamics in this key international market.

\section{Methodology, Empirical Model, and Data}

Price dynamics and transmission between two geographically separated exporters in a specific market can display various patterns due to different levels of market integration [24-26], market scenarios [27], and policy uncertainty [28]. Over the years spatial price dynamics and transmission for food commodities have been extensively explored in the literature, with different econometric models being developed and applied to empirical studies: Abdulai [27] utilizes threshold cointegrating models to reveal asymmetric market signals transmission and responses between central and local maize markets. The switching regime VECM model employed by Goodwin and Piggott [26] investigates price linkages among different corn and soybean regional markets in North Carolina, the US. Non-parametric regressions and non-linear threshold models have been compared to estimate asymmetric price adjustments in spatially separate pig markets within the EU [29]. Nonlinear autoregressive distributed lag model, as well as nonparametric kernel-based and time-varying copulas, are employed to assess asymmetric spatial price linkages and market integration and co-movement of monthly SMP prices among the US, the EU and Oceania markets [24,30]. Despite plenty of time series applications, the studies on the dairy industry spatially are relatively rare.

This section explains relevant methodologies including both the linear and non-linear cointegration models, including the error correction model, and four types of threshold models [31-33], and how they are employed in our study to empirically address SMP export price transmission dynamics for Ireland and New Zealand.

\subsection{Linear Cointegration Analysis}

The Granger-Engle cointegration model named after Engle and Granger [32] is a two-step procedure for cointegration analysis to solve the problem of spurious regression. The way of detecting the cointegrating relationship is to first establish a long-run 
equilibrium equation and then to test the stationarity of the residuals derived from the acquired equation.

Step 1: The Granger-Engle long-run equilibrium equation for two variables could be constructed as Equation (1), whose parameters can be estimated by OLS regression.

$$
Y_{t}=\alpha_{0}+\alpha_{1} X_{t}+\varepsilon_{t}
$$

where $X_{t}$ is the vector of driving time series variable, $Y_{t}$ is the vector of another time series variable, $\alpha_{0}$ and $\alpha_{1}$ are coefficients, $\varepsilon_{t}$ is the error term.

Step 2: An Augmented Dicken-Fuller (ADF) test [34] was performed on the residuals $\hat{\varepsilon}_{\mathrm{t}}$ to determine whether the residuals are stationary. If so, then the two nonstationary variables of I (1) can be regarded as cointegrated. To be more specifical, the number of lags was selected by Akaike Information Criterion (AIC), Bayesian Information Criterion (BIC), or Ljung-Box $\mathrm{Q}$ test to ensure that there is no serial correlation in the regression residuals, that is, the residuals $\mu_{t}$ in Equation (2) could be considered as white noise. Therefore, if the null hypothesis of $\rho=0$ is rejected, it can be concluded that $Y_{t}$ and $X_{t}$ are integrated.

$$
\Delta \hat{\varepsilon_{\mathrm{t}}}=\rho \widehat{\varepsilon_{\mathrm{t}-1}}+\sum_{\mathrm{i}=1}^{\mathrm{p}} \varphi_{\mathrm{i}} \Delta \widehat{\varepsilon_{\mathrm{t}-\mathrm{i}}}+\mu_{\mathrm{t}}
$$

where $\rho$ is the coefficient of residuals, $\varphi_{\mathrm{i}}$ is the coefficient vector of residual differences in different lag orders, $\mu_{\mathrm{t}}$ is a white noise with zero mean and constant variance, which is identically and independently distributed, $\Delta$ is the first difference indicator, $\hat{\varepsilon}_{\mathrm{t}}$ is the estimated residuals and $p$ represents the lag orders.

\subsection{Non-Linear Cointegration Analysis}

The threshold autoregressive (TAR) model proposed by Tong [33] facilitates the capture of the "deep" movements in a series and investigate whether troughs in the series are more persistent than peaks or vice versa. Therefore, the TAR approach was employed to uncover the SMP export price relationships among the average world and regional markets or different exporters in the same market. In addition, asymmetries in price adjustments to positive or negative deviations can be obtained through the TAR model.

Alternatively, Momentum-Threshold Autoregressive (M-TAR) model could capture the attempt to mitigate or eliminate large changes in a series.

Equation (2) can be written in an alternative specification as

$$
\Delta \hat{\varepsilon_{\mathrm{t}}}=\rho_{1} \mathrm{I}_{\mathrm{t}} \widehat{\varepsilon_{\mathrm{t}-1}}+\rho_{2}\left(1-\mathrm{I}_{\mathrm{t}}\right) \widehat{\varepsilon_{\mathrm{t}-1}}+\sum_{\mathrm{i}=1}^{\mathrm{p}} \varphi_{\mathrm{i}} \Delta \widehat{\varepsilon_{\mathrm{t}-\mathrm{i}}}+\mu_{\mathrm{t}}
$$

where $\rho_{1}$ is the coefficient of positive deviation, and $\rho_{2}$ is the coefficient of negative deviation, $I_{t}$ is the Heaviside indicator function that can be set as following equations:

$$
\begin{aligned}
& \mathrm{I}_{\mathrm{t}}=1 \text { if } \widehat{\varepsilon_{\mathrm{t}-1}} \geq \tau, 0 \text { otherwise; or } \\
& \mathrm{I}_{\mathrm{t}}=1 \text { if } \widehat{\Delta \varepsilon_{\mathrm{t}-1}} \geq \tau, 0 \text { otherwise; }
\end{aligned}
$$

and $\tau$ is the value of the threshold, $\mu_{t}$ is the identically and independently distributed white noise with mean zero and constant variance. If the Heaviside indicator depends on the level of $\widehat{\varepsilon_{t-1}}$ as indicated in Equation (4), then Equation (3) is the representation form of the Threshold Autoregressive Model (TAR). If the Heaviside indicator relies on the previous period's change in $\widehat{\varepsilon_{\mathrm{t}-1}}$ as Equation (5), then Equation (3) is the representation form of M-TAR Model. If $\left|\rho_{1}\right|<\left|\rho_{2}\right|$, a negative realization of $\widehat{\Delta \varepsilon_{t-1}}$ decays faster than the positive one, then the increases tend to persist, whereas decreases are sharper and more significant, thereby tending to revert rapidly towards equilibrium. This pattern would be reversed if $\left|\rho_{1}\right|>\left|\rho_{2}\right|[31,35]$. 


\subsection{Asymmetric Error Correction Model with Threshold Cointegration}

Provided that there is only one cointegrating relationship in the form of Equation (1), the Asymmetric Error-correction Models with Threshold cointegration can be constructed as the following specifications.

$$
\begin{aligned}
& \Delta X_{t}=\theta_{X}+\delta_{X}^{+} E_{t-1}^{+}+\delta_{X}^{-} E_{t-1}^{-}+\sum_{j=1}^{J} \alpha_{X_{j}}^{+} \Delta X_{t-j}^{+}+\sum_{j=1}^{J} \alpha_{X_{j}}^{-} \Delta X_{t-j}^{-}+\sum_{j=1}^{J} \beta_{X_{j}}^{+} \Delta Y_{t-j}^{+}+\sum_{j=1}^{J} \beta_{X_{j}}^{-} \Delta Y_{t-j}^{-}+\vartheta_{X_{t}} \\
& \Delta Y_{t}=\theta_{Y}+\delta_{Y}^{+} E_{t-1}^{+}+\delta_{Y}^{-} E_{t-1}^{-}+\sum_{j=1}^{J} \alpha_{Y_{j}}^{+} \Delta X_{t-j}^{+}+\sum_{j=1}^{J} \alpha_{Y_{j}}^{-} \Delta X_{t-j}^{-}+\sum_{j=1}^{J} \beta_{Y_{j}}^{+} \Delta Y_{t-j}^{+}+\sum_{j=1}^{J} \beta_{Y_{j}}^{-} \Delta Y_{t-j}^{-}+\vartheta_{Y_{t}}
\end{aligned}
$$

where $\Delta \mathrm{X}$ and $\Delta \mathrm{Y}$ are driving price and dependent price in first difference respectively, $\alpha_{X_{j}}^{+}$ is the coefficient of positive deviations of vector $X$ for Equation (6), $\alpha_{X_{j}}^{-}$is the coefficient of negative deviations of vector $X$ for Equation (6), $\beta_{X_{j}}^{+}$is the coefficient of positive deviations of vector $Y$ for Equation (6), $\beta_{X_{j}}^{-}$is the coefficient of negative deviations of vector $Y$ for Equation (6), $\alpha_{Y_{j}}^{+}$is the coefficient of positive deviations of vector $X$ for Equation (7), $\alpha_{Y_{j}}^{-}$is the coefficient of positive deviations of vector $X$ for Equation (7), $\beta_{Y_{j}}^{+}$is the coefficient of positive deviations of vector $X$ for Equation (7), $\beta_{Y_{j}}^{-}$is the coefficient of negative deviations of vector $Y$ for Equation (7); $\theta_{X}$ and $\theta_{Y}$ are intercepts, $\delta^{+}$and $\delta^{-}$are the coefficients of positive and negative Error-Correction terms, respectively, and $\vartheta$ is the error term. The subscribes $t$ and $j$ indicate time and lags, respectively. In Equations (6) and (7), the positive and the negative variables were subjects to the following example Equations:

$$
\begin{aligned}
& \Delta X_{t-j}^{+}= \begin{cases}X_{t-j}-X_{t-j-1}, & \text { if } X_{t-j}>X_{t-j-1} \\
0, & \text { if } X_{t-j} \leq X_{t-j-1}\end{cases} \\
& \Delta X_{t-j}^{-}= \begin{cases}X_{t-j}-X_{t-j-1}, & \text { if } X_{t-j}<X_{t-j-1} \\
0, & \text { if } X_{t-j} \geq X_{t-j-1}\end{cases}
\end{aligned}
$$

The error correction term E defined as $\mathrm{E}_{\mathrm{t}-1}^{+}=\mathrm{I}_{\mathrm{t}} \widehat{\varepsilon_{\mathrm{t}-1}}$ and $\mathrm{E}_{\mathrm{t}-1}^{-}=\left(1-\mathrm{I}_{\mathrm{t}}\right) \widehat{\varepsilon_{\mathrm{t}-1}}$, reveals possible asymmetric prices in response to positive and negative deviations from the longterm equilibrium, along with the impact of threshold cointegration. $I_{t}$ is the Heaviside indicator in Equations (4) and (5). As $X$ represents the driving force and the long-term disequilibrium is measured as the difference between $X$ and $Y$, thus the signs of the coefficients for error correction terms should be $\delta X^{+}>0, \delta X^{-}>0$ and $\delta_{Y}{ }^{+}<0, \delta_{Y}{ }^{-}<0$. The maximum lags $\mathrm{j}$ is selected by AIC statistics and Ljung-Box $\mathrm{Q}$ test.

\subsection{Empirical Models and Hypothesis}

Considering that China has been a global leader in milk powder imports, especially those from New Zealand, and with Ireland trying to expand its dairy market share and market returns in China, three relationships based on our assumptions of export prices were studied in this paper.

First, the relationship between export prices from Ireland in global markets, $\mathrm{p}_{\mathrm{ie}^{\prime}}^{\mathrm{W}}$, and prices in the Chinese market, $\mathrm{p}_{\mathrm{i} \text {, }}^{\mathrm{c}}$, with the latter as the driving force, was analysed, namely $\mathrm{Y}_{\mathrm{t}}=\mathrm{p}_{\mathrm{ie}}^{\mathrm{W}}$ and $\mathrm{X}_{\mathrm{t}}=\mathrm{p}_{\mathrm{ie}}^{\mathrm{c}}$. The correlation of the two price series was estimated to be 0.75 .

Second, export prices from New Zealand to the Chinese market, $\mathrm{p}_{\mathrm{nz}}^{\mathrm{c}}$, was assumed to be the driving force of New Zealand's export prices in the global markets, $\mathrm{p}_{\mathrm{nz}}^{\mathrm{W}}$. Therefore, in this case: $Y_{t}=p_{n z}^{w}$ and $X_{t}=p_{n z}^{c}$. The correlation of the two price series was estimated as 0.52 .

Finally, the third relationship was estimated between export prices in the Chinese market from New Zealand, $\mathrm{p}_{\mathrm{nz}}^{\mathrm{c}}$, and from Ireland, $\mathrm{p}_{\mathrm{ie}}^{\mathrm{c}}$, in which, the price of New Zealand was designated as the driving force, i.e., $Y_{t}=p_{i e}^{c}$ and $X_{t}=p_{n z}^{c}$. The correlation of the two price series was 0.87 .

The first two relationships were to identify the dominant position of export destination and market integration between a specific market, i.e., China and the global market, and 
the third relationship was estimated to identify price leadership between a dominant player (New Zealand) and a new player (Ireland) in the Chinese market.

\subsection{Data and Software}

As mentioned above, three pairs of SMP export price relationships were explored in the study, including prices set by Ireland in the Chinese market and in the global market, the prices set by New Zealand in the Chinese market and in the global market, and the prices of Ireland and New Zealand in the Chinese market. Trade data for New Zealand was extracted from the UN Comtrade and trade data for Ireland was extracted from Eurostat due to a large amount of missing data for Ireland in the UN Comtrade dataset. The commodity of Skim Milk Powder (SMP) was classified according to the Harmonises System classification at 6 digits of detail (HS6) as HS 040210 (Milk and Cream in Solid Forms, of A Fat Content by Weight $\leq 1.5 \%$.).

Monthly data from January 2010 to December 2016 was used for this study. The export price from New Zealand in US dollars was calculated using the equation: $p_{n z}^{h}=\frac{V_{n z}^{h}}{Q_{n z}^{h}}$, where $\mathrm{V}_{\mathrm{nz}}^{\mathrm{h}}$ is the total export value in US dollars and $\mathrm{Q}_{\mathrm{nz}}^{\mathrm{h}}$ is the total export weight in kilogram. While the export prices from Ireland in US dollars was calculated using the equation: $\mathrm{p}_{\mathrm{ie}}^{\mathrm{h}}=\frac{\mathrm{V}_{\mathrm{ie}}^{\mathrm{h}}}{\mathrm{Q}_{\mathrm{ie}}^{\mathrm{h}}} * \mathrm{er}_{\text {euro }}$, where $\mathrm{V}_{\mathrm{ie}}^{\mathrm{h}}$ is the total export value in euro, $\mathrm{Q}_{\mathrm{ie}}^{\mathrm{h}}$ is the total export weight in kilogram, and er euro $_{\text {is }}$ the exchange rate for the conversion of one euro to the US dollars extracted from International Financial Statistics (IFS), h symbolizes the destinations for export, namely, China and the world. All the export values are FOB (free-on-board) values.

In this study, the software R studio was used for statistical analysis and Microsoft Excel for the depiction of figures. Specifically, the R package apt created by Sun [36] was applied for the analysis.

\subsection{Descriptive Statistics and the Unit Root Test Results for the Price Series}

The descriptive statistics of price series from January 2010 to December 2016 used in this study are outlined in Table 1 and the time series are plotted in Figure 1.

Table 1. Descriptive statistics for the export prices of Ireland and New Zealand.

\begin{tabular}{ccccc}
\hline \multirow{2}{*}{ Statistic } & \multicolumn{2}{c}{ Ireland } & \multicolumn{2}{c}{ New Zealand } \\
\cline { 2 - 5 } & World Level & China Level & World Level & China Level \\
\hline Mean & 2.927 & 3.340 & 2.861 & 3.217 \\
Minimum & 1.359 & 1.921 & 1.760 & 1.760 \\
Maximum & 4.599 & 7.097 & 5.055 & 5.164 \\
Std. Dev. & 0.785 & 0.887 & 0.821 & 0.850 \\
\hline
\end{tabular}

From January 2010 to December 2016, Ireland's average export prices globally and in Chinese markets were 2.927 US dollars per kilogram and 3.340 US dollars per kilogram, respectively; while New Zealand's average export prices were 2.861 US dollars per kilogram and 3.217 US dollars per kilogram, respectively. Generally, according to the descriptive statistics, export prices for the Chinese market are higher than for the global market, and also export prices from Ireland are higher than from New Zealand. It is probably because New Zealand and China have a free trade agreement that substantially lowers tariff duty rates to 1.7\%, while China's most favored nation (MFN) tariffs for SMP is 10\% (Data source: WTO Tariff Download Facility). 


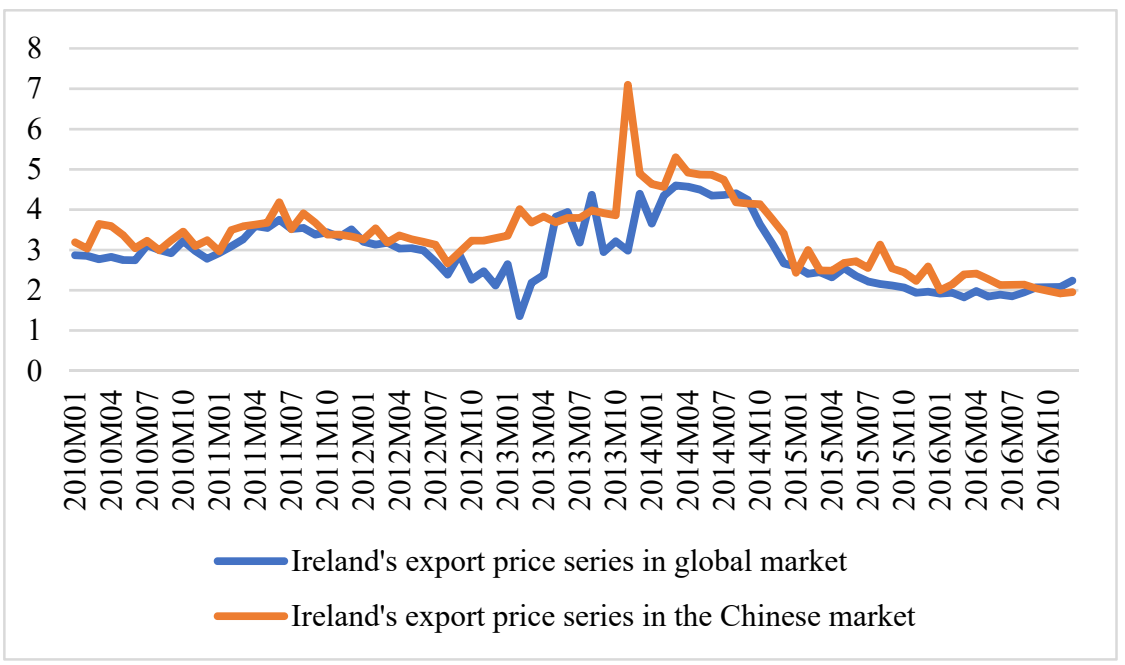

Figure 1. Monthly SMP export prices for Ireland to the Chinese market and globally between January 2010 and December 2016.

As depicted in Figures 1-3, the export prices for both the countries were much more stable before 2013 and displayed a co-movement pattern over time, after which they have obvious spikes and troughs with large fluctuations in the years 2013 to 2015. The main reasons behind these price fluctuations analysed by Bord Bia Report $[14,37,38]$ are: (a) A cold wet spring in Europe and the worst drought in New Zealand for 75 years, along with weak production in China resulted in low dairy supply in 2013. (b) The demand from China remained high in 2013, resulting in intensive stock building in 2013 and early 2014. (c) In 2014, domestic production was higher than expected while China's economic growth slowed down. (d) High retail prices in late 2013 and early 2014 reduced import demand both in the Chinese and global markets and the oil price fell. However, fluctuations have died down since 2015 with prices dropping to low levels. Overall, as illustrated in Figure 1, export prices from Ireland and New Zealand appear to have a co-movement pattern and Ireland's export prices follow New Zealand's price changes with greater fluctuations. Thus, New Zealand, to a certain degree, may have been the price leading country for SMP exports both in global and in Chinese markets.

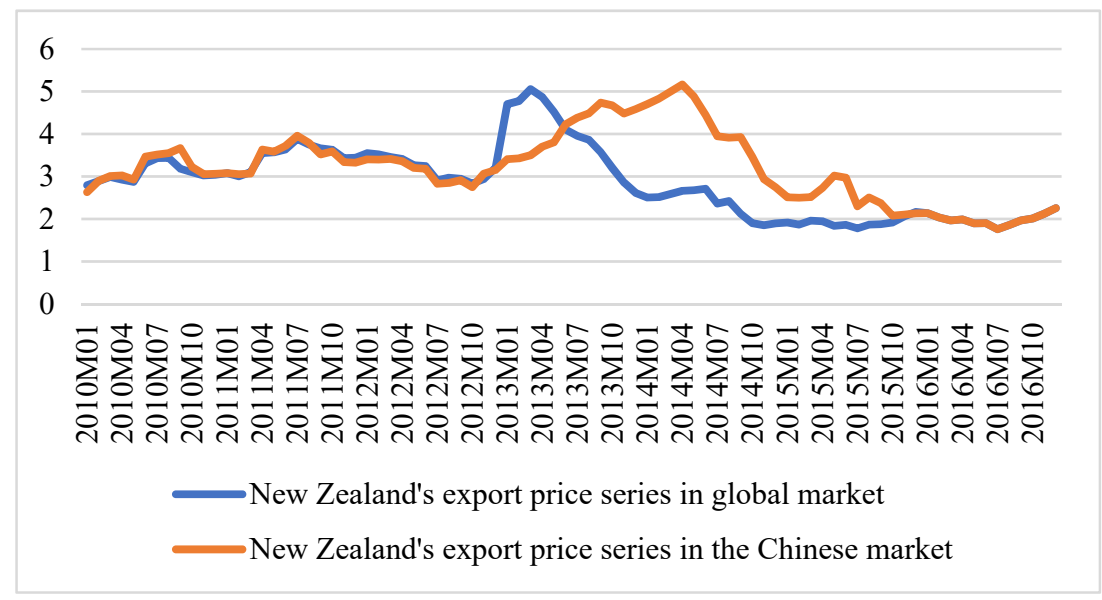

Figure 2. Monthly SMP export prices for New Zealand to the Chinese market and globally between January 2010 and December 2016. 


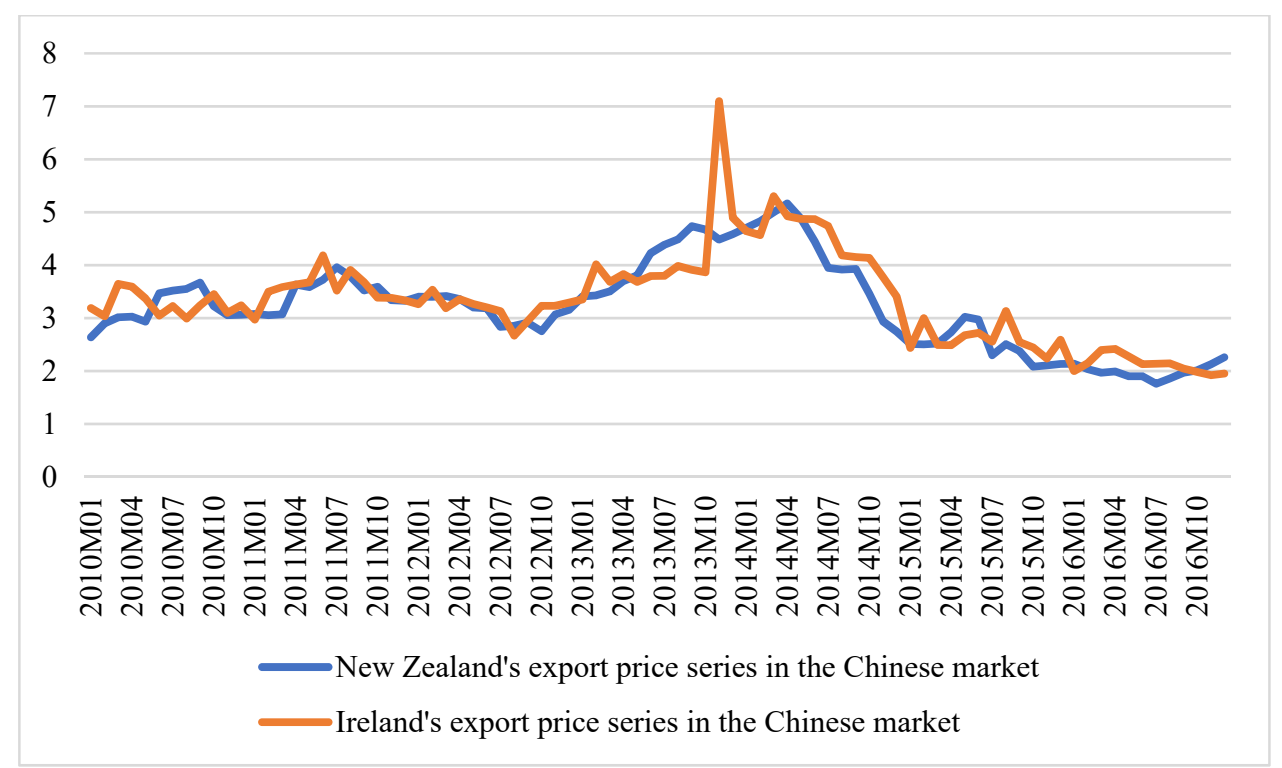

Figure 3. Monthly SMP export prices for Ireland and New Zealand to Chinese market between January 2010 and December 2016.

To analyse the price series using proper time series models. The first step is to test the stationarity of all series. The Augmented Dicken-Fuller (ADF) and Phillips-Perron (PP) united root tests were conducted for the price series outlined in Table 2.

Table 2. The unit root tests results for the export prices of Ireland and New Zealand.

\begin{tabular}{ccccccccc}
\hline \multirow{2}{*}{ Statistic } & \multicolumn{2}{c}{ Ireland } & \multicolumn{2}{c}{ Ireland } & \multicolumn{2}{c}{ New Zealand } & \multicolumn{2}{c}{ New Zealand } \\
\cline { 2 - 8 } & World Level & 1st Diff & China Level & 1st Diff & World Level & 1st Diff & China Level & 1st Diff \\
\hline \multirow{2}{*}{ ADF test } & -2.288 & -4.082 & -1.346 & -4.111 & -2.757 & -4.220 & -2.053 & -3.664 \\
& $(0.458)$ & $(0.01)$ & $(0.844)$ & $(0.01)$ & $(0.265)$ & $(0.01)$ & $(0.554)$ & $(0.033)$ \\
PP test & -2.050 & & -2.59 & & -1.62 & & -1.42 & $(0.57)$ \\
\hline
\end{tabular}

Note: $p$-value in brackets.

The hypothesis of non-stationarity couldn't be rejected at the $10 \%$ level, while it could be rejected at the $1 \%$ level for the first-differenced form. All the price series are non-stationary and are one-order integrated. Therefore, accessing cointegration relationships could be processed to figure out whether the two countries' prices could have long-run relationships.

\section{Empirical Results for Own-Country Price Relationships}

In this section, the empirical results for own-country price relationships are demonstrated.

\subsection{Relationship of Irish SMP Export Prices in Chinese and Global Markets}

Table 3 outlines the results for the Engle-Granger and threshold cointegration tests for Irish SMP export prices. As shown in the methodology part of Section 3.1, the model representation of the Granger-Engle test is as Equation (2): $\left.\Delta \hat{\varepsilon}_{\mathrm{t}}=\rho \widehat{\varepsilon_{\mathrm{t}-1}}+\sum_{\mathrm{i}=1}^{\mathrm{p}}\right] \varphi_{\mathrm{i}} \Delta \widehat{\varepsilon_{\mathrm{t}-\mathrm{i}}}+\mu_{\mathrm{t}}$, and the model representation of threshold cointegration test is as Equation (3): $\Delta \widehat{\varepsilon_{\mathrm{t}}}=\rho_{1} \mathrm{I}_{\mathrm{t}} \widehat{\varepsilon_{\mathrm{t}-1}}+\rho_{2}\left(1-\mathrm{I}_{\mathrm{t}}\right) \widehat{\varepsilon_{\mathrm{t}-1}}+\sum_{\mathrm{i}=1}^{\mathrm{p}} \varphi_{\mathrm{i}} \Delta \widehat{\varepsilon_{\mathrm{t}-\mathrm{i}}}+\mu_{\mathrm{t}}$. Both Equations (2) and (3) are based on the error of Equation (1) $Y_{t}=\alpha_{0}+\alpha_{1} X_{t}+\varepsilon_{t}$, where $X_{t}$ is the vector of Ireland's export price in the Chinese market, $p_{i e}^{c}$, and $Y_{t}$ is the vector of Ireland's export price in the world market, $\mathrm{p}_{\mathrm{ie}}^{\mathrm{W}}$. The best lag selected by AIC and BIC is 2, so $p=2$ for Equations (2) and (3). 
Table 3. Engle-Granger and threshold cointegration tests results for Irish SMP export prices.

\begin{tabular}{|c|c|c|c|c|c|}
\hline Item & Engle-Granger & TAR & Consistent TAR & MTAR & Consistent MTAR \\
\hline \multicolumn{6}{|c|}{ Estimate } \\
\hline Intercept & $\begin{array}{c}0.722^{* * *} \\
(3.21)\end{array}$ & $\begin{array}{c}0.722 \text { *** } \\
(3.21)\end{array}$ & $\begin{array}{c}0.722^{* * *} \\
(3.21)\end{array}$ & $\begin{array}{c}0.722^{* * *} \\
(3.21)\end{array}$ & $\begin{array}{c}0.722^{* * *} \\
(3.21)\end{array}$ \\
\hline Export price to China, $\mathrm{p}_{\mathrm{ie}}^{\mathrm{c}}$ & $\begin{array}{c}0.660^{* * *} \\
(10.14)\end{array}$ & $\begin{array}{c}0.660^{* * *} \\
(10.14)\end{array}$ & $\begin{array}{c}0.660^{* * *} \\
(10.14)\end{array}$ & $\begin{array}{c}0.660^{* * *} \\
(10.14)\end{array}$ & $\begin{array}{c}0.660^{* * *} \\
(10.14)\end{array}$ \\
\hline Threshold & - & 0 & -0.360 & 0 & 0.098 \\
\hline$\rho_{1}$ & $\begin{array}{l}-0.424^{* * *} \\
(-3.538)\end{array}$ & $\begin{array}{l}-0.361 * \\
(-1.978)\end{array}$ & $\begin{array}{l}-0.275 \# \\
(-1.662)\end{array}$ & $\begin{array}{l}-0.402 * * \\
(-2.346)\end{array}$ & $\begin{array}{l}-0.176 \\
(-0.928)\end{array}$ \\
\hline$\rho_{2}$ & - & $\begin{array}{l}-0.624^{* * *} \\
(-4.386)\end{array}$ & $\begin{array}{l}-0.719 * * * \\
(-4.947)\end{array}$ & $\begin{array}{c}-0.629 * * * \\
(-4.179)\end{array}$ & $\begin{array}{l}-0.681^{* * *} \\
(-5.035)\end{array}$ \\
\hline$\varphi_{1}$ & - & $\begin{array}{l}-0.143 \\
(-1.084)\end{array}$ & $\begin{array}{c}-0.129 \\
(-0.997)\end{array}$ & $\begin{array}{l}-0.125 \\
(-0.936)\end{array}$ & $\begin{array}{l}-0.142 \\
(-1.105)\end{array}$ \\
\hline$\varphi_{2}$ & - & $\begin{array}{l}0.265 * \\
(2.451)\end{array}$ & $\begin{array}{l}0.277 * \\
(2.615)\end{array}$ & $\begin{array}{l}0.271 * \\
(2.490)\end{array}$ & $\begin{array}{l}0.261 * \\
(2.476)\end{array}$ \\
\hline \multicolumn{6}{|c|}{ Diagnostics } \\
\hline AIC & 134.339 & 107.17 & 103.441 & 107.627 & 102.832 \\
\hline $\mathrm{BIC}$ & 141.632 & 119.142 & 115.413 & 119.599 & 114.804 \\
\hline $\mathrm{R}^{2}$ & 0.5567 & 0.4641 & 0.4882 & 0.461 & 0.492 \\
\hline QLB(4) & 0.2595 & 0.513 & 0.431 & 0.452 & 0.495 \\
\hline QLB(8) & 0.03954 & 0.086 & 0.096 & 0.078 & 0.166 \\
\hline QLB(12) & 0.01474 & 0.027 & 0.049 & 0.037 & 0.131 \\
\hline \multicolumn{6}{|c|}{ Hypotheses } \\
\hline$\Phi\left(H 0: \rho_{1}=\rho_{2}=0\right)$ & - & $\begin{array}{c}10.04 \\
(<0.001)\end{array}$ & $\begin{array}{c}12.328 \\
(<0.001)\end{array}$ & $\begin{array}{c}9.767 \\
(<0.001)\end{array}$ & $\begin{array}{c}12.711 \\
(<0.001)\end{array}$ \\
\hline $\mathrm{F}\left(H 0: \rho_{1}=\rho_{2}\right)$ & - & $\begin{array}{c}1.712 \\
(0.195)\end{array}$ & $\begin{array}{c}5.421 \\
(0.023)\end{array}$ & $\begin{array}{c}1.269 \\
(0.263)\end{array}$ & $\begin{array}{c}6.042 \\
(0.016)\end{array}$ \\
\hline
\end{tabular}

Note: $p$-value $<0.001$, denoted as ${ }^{\star * * * \prime} ; p$-value $<0.01$, denoted as ${ }^{\star * * \prime} ; p$-value $<0.05$, denoted as ${ }^{` \prime \prime} ; p$-value $<0.1$, denoted as ' $\#^{\prime}$. $p$-value in the brackets.

\subsubsection{Engle-Granger Cointegration Analysis}

The linear cointegration analysis was conducted through the Engle-Granger cointegration test which consisted of two steps. First, the linear relationship between Irish SMP export prices in the global Chinese market was estimated with results shown in Equation (10). The coefficient is 0.66 and is significant at the $1 \%$ level. Secondly, the augmented Dicken-Fuller unit root test was performed on the residuals with lags equalling to 1 selected by AIC statistic. Therefore, Irish SMP global and Chinese export prices have a cointegrating relationship when tested using the Engle-Granger approach. As reported in Table 3 , the statistical value is estimated as -0.424 , which is significant at the $1 \%$ level.

$$
\mathrm{p}_{\mathrm{ie}}^{\mathrm{w}}=\begin{gathered}
0.72186 \\
(0.00189)
\end{gathered}+\begin{gathered}
0.66049 \\
\left(3.82 * 10^{-16}\right)
\end{gathered} \mathrm{p}_{\mathrm{ie}}^{\mathrm{c}}+\varepsilon_{\mathrm{t}}
$$

\subsubsection{Non-Linear Threshold Cointegration Analysis}

The threshold autoregressive models were applied to study the nonlinear cointegration analysis. The method proposed by Chan [39] was applied to determine the threshold estimate [35]. Different lags ranging from 1 to 12 were performed to select the best lag. According to the AIC statistics, the best lag for the models was lag 2. In Table 3, the four models (i.e., TAR, MTAR, Consistent TAR and Consistent MTAR) estimated with the selected lag 2 is reported.

In the case of Ireland, the consistent MTAR model was the best fit for the relationship between the export price for Chinese and global markets, because both the AIC statistic of 102.832 and the BIC statistic of 114.804 were the lowest in the four threshold models. More- 
over, the hypotheses of no cointegration and asymmetric transmission were rejected at $1 \%$ and $2 \%$ significance levels, respectively. Therefore, the adjustment process was asymmetric when export prices to the world and to China adjust to achieve long-run equilibrium. The point estimate of this consistent MTAR for the price adjustment was -0.176 for positive shocks but was -0.681 for negative shocks. So, if there was an above-threshold deviation from the long-term equilibrium caused by increases in world prices or decreases in Chinese prices $\left(\widehat{\varepsilon_{t-1}} \geq 0.098\right)$, this deviation would have been corrected at the speed of $17.6 \%$ per month. If there was a below-threshold deviation due to prices decreases in the global market or price increases in China $\left(\widehat{\varepsilon_{\mathrm{t}-1}} \leq 0.098\right)$, this deviation would have been corrected at a speed of $68.1 \%$ per month. Thus, the convergence for above-threshold deviations from long-run equilibrium is almost 4.2 months $(1 / 0.176-1 / 0.681=4.2$ months $)$ slower than below-threshold deviations. Moreover, the result that transmission is asymmetric can be indicated by the consistency of the MTAR model with the results of the other three models. This is consistent with results found by Abdulai [27] that wholesale maize prices in local markets respond more rapidly to price increases in the central market, and that different local markets react at different rates to price changes in the central market.

\subsubsection{Error Correction Model Results Analysis}

Table 4 outlines the results of the asymmetric error correction model with threshold cointegration for Irish SMP export prices.

Table 4. Results of the asymmetric error correction model with threshold cointegration for Ireland.

\begin{tabular}{|c|c|c|c|c|}
\hline & \multicolumn{2}{|c|}{ Ireland China } & \multicolumn{2}{|c|}{ Ireland World } \\
\hline & Estimation & T-Ratio & Estimation & T-Ratio \\
\hline (Intercept) & -0.016 & -0.215 & 0.003 & 0.051 \\
\hline$\alpha_{i 1}^{+}$ & $-0.672^{* * *}$ & -4.056 & -0.043 & -0.308 \\
\hline$\alpha_{i 2}^{+}$ & -0.066 & -0.28 & -0.069 & -0.351 \\
\hline$\alpha_{i 1}^{-12}$ & 0.062 & 0.223 & -0.043 & -0.183 \\
\hline$\alpha_{i 2}^{11}$ & 0.126 & 0.755 & -0.102 & -0.728 \\
\hline$\beta_{\mathrm{i} 1}^{+1}$ & -0.222 & -0.931 & -0.229 & -1.146 \\
\hline$\beta_{i 2}^{+1}$ & $0.36 \#$ & 1.798 & 0.219 & 1.305 \\
\hline$\beta_{\mathrm{i} 1}^{-12}$ & 0.318 & 1.348 & 0.04 & 0.203 \\
\hline$\beta_{\mathrm{i} 2}^{-\frac{11}{2}}$ & $-1.022 * * *$ & -4.584 & 0.26 & 1.393 \\
\hline$\delta_{i}^{+2}$ & 0.151 & 0.746 & -0.201 & -1.181 \\
\hline$\delta_{i}^{-}$ & -0.014 & -0.088 & $-0.528^{* * *}$ & -4.027 \\
\hline $\mathrm{R}^{2}$ & 0.479 & - & 0.444 & - \\
\hline AIC & 97.892 & - & 69.327 & - \\
\hline $\mathrm{BIC}$ & 126.625 & - & 98.060 & - \\
\hline QLB(4) & 0.839 & - & 0.641 & - \\
\hline QLB(8) & 0.320 & - & 0.156 & - \\
\hline$F$-statistics & \multicolumn{2}{|c|}{$6.44(<0.001)$} & \multicolumn{2}{|c|}{$10.61(<0.001)$} \\
\hline
\end{tabular}

An asymmetric error correction model with consistent MTAR was estimated and the results obtained have been outlined in Table 4 . Three coefficients (i.e., $\alpha_{\text {china1 }}^{+}, \beta_{\text {china2 }}^{+}$and $\beta_{\text {china2 }}^{-}$) were significant at the level of $10 \%$ in the Chinese market price equation, while only one coefficient $\delta_{\text {world }}^{-}$was significant at the $10 \%$ level in the global market price equation. Additionally, the squared $R$ statistic was 0.479 for the China equation and was 0.444 for the world equation. However, the AIC and BIC statistics for the world equation were lower than that of the China equation. The $F$ statistics for the overall fitness of the AECM-C-MTAR models were significant at the level of $1 \%$ for both China and world equations.

In the world equation, the estimate of the positive error correction term $\delta_{\text {world }}^{+}$was -0.201 and the estimate of the negative term $\delta_{\text {world }}^{-}$was -0.528 in the world equation. In the short-run, the global export price of Ireland adjusted at different speeds when there 
were positive and negative deviations, and the global price has a slower correction speed to positive deviations from the long-run equilibrium than to negative deviations from the long-run equilibrium between global price and Chinese price. When the price series encounters shocks, the adjustment of the price series in the global market exhibits more "momentum" in the direction of rising prices in the global market or decreasing prices in the Chinese market than the direction of decreasing price in the global market or increasing price in the Chinese market. The factors behind this spatial transmission pattern may be due to the CAP policy of the SMP stocks and intervention prices from the EU to stabilize price if global price decreases. Also, it could be because that the market share in the Chinese market is relatively small, Ireland has more freedom to adjust its export prices to make arbitrage in the Chinese market and to avoid high volatility of its overall export prices.

In the China equation, the estimates for the coefficient of the positive error correction term $\delta_{\text {china }}^{+}$was 0.151 and the coefficient of the negative error correction term $\delta_{\text {china }}^{-}$ was -0.014 . Neither of the coefficients is significant at the level of $10 \%$. Therefore, the export price of Ireland to the Chinese market could converge to long-run equilibrium symmetrically regardless of the positive or negative deviations. So, in the short run, SMP export prices to China respond more rapidly to increases in export prices in global markets than to price decreases in global markets. When the price series encounters shocks, the adjustment of the price series in the global market exhibits more "momentum" in the direction of rising prices. The factors behind this transmission pattern may be due to the application of the SMP stocks and intervention prices from the EU. Also, the Irish share of the Chinese market is relatively small, so Ireland has more freedom to adjust its export prices to arbitrage in the Chinese market and thus avoid a higher risk to its overall export prices.

\subsection{Relationship of New Zealand's SMP Export Prices in Chinese and Global Markets}

Table 5 outlines results for the Engle-Granger and threshold cointegration tests based on Equations (2) and (3) in Section 3.1 for New Zealand SMP export prices. Both Equations (2) and (3) are based on the error of Equation (1) $Y_{t}=\alpha_{0}+\alpha_{1} X_{t}+\varepsilon_{t}$, where $X_{t}$ is the vector of New Zealand's export price in the Chinese market, $p_{n z}^{c}, Y_{t}$ is the vector of New Zealand's export price in the world market, $\mathrm{p}_{\mathrm{nz}}^{\mathrm{w}}$.

\subsubsection{Engle-Granger Cointegration Analysis}

The relationship between the export price of New Zealand in global and Chinese markets was also estimated to be cointegrated. The linear relationship of Irish SMP export prices in the global and in the Chinese market was estimated with results shown in Equation (11) below, the linear regression coefficient was 0.50 and significant at the level of $1 \%$. The statistic value of -2.07 was reported in Table 5 and is significant at the $5 \%$ level, which indicates that the export prices of New Zealand in the world and in the Chinese markets are well cointegrated in the long run.

$$
\mathrm{p}_{\mathrm{nz}}^{\mathrm{w}}=\begin{gathered}
1.25221 \\
\left(8.69 * 10^{-5}\right)
\end{gathered}+\begin{gathered}
0.50017 \\
\left(4.43 * 10^{-7}\right)
\end{gathered} \mathrm{p}_{\mathrm{nz}}^{\mathrm{c}}+\varepsilon_{\mathrm{t}}
$$

\subsubsection{Non-Linear Threshold Cointegration Analysis}

In the case of New Zealand, the consistent TAR model fits best with the relationship between export prices for the Chinese market and export prices for the global market, with the lowest AIC statistic of -25.691 and the lowest BIC statistic of -13.718 . The hypothesis for no cointegration was rejected at the significance level of $1 \%$ in all models. Based on the estimations obtained from the consistent TVAR, the adjustment process was asymmetric when export prices in global and Chinese markets adjusted to achieve the long-term equilibrium because the hypothesis for symmetric adjustment was rejected at the significance level of $5 \%$. 
Table 5. Results of Engle-Granger and threshold cointegration tests for New Zealand SMP export prices.

\begin{tabular}{|c|c|c|c|c|c|}
\hline Item & Engle-Granger & TAR & Consistent TAR & MTAR & Consistent MTAR \\
\hline \multicolumn{6}{|c|}{ Estimate } \\
\hline Intercept & $\begin{array}{l}1.252^{* * *} \\
(0.303)\end{array}$ & $\begin{array}{l}1.252 * * * \\
(0.303)\end{array}$ & $\begin{array}{l}1.252 * * * \\
(0.303)\end{array}$ & $\begin{array}{l}1.252^{* * *} \\
(0.303)\end{array}$ & $\begin{array}{l}1.252^{* * *} \\
(0.303)\end{array}$ \\
\hline Export price to China, $\mathrm{p}_{n z}^{\mathrm{c}}$ & $\begin{array}{c}0.500^{* * *} \\
(0.091)\end{array}$ & $\begin{array}{c}0.500^{* * *} \\
(0.091)\end{array}$ & $\begin{array}{c}0.500^{* * *} \\
(0.091)\end{array}$ & $\begin{array}{c}0.500^{* * *} \\
(0.091)\end{array}$ & $\begin{array}{c}0.500^{* * *} \\
(0.091)\end{array}$ \\
\hline $\begin{array}{c}\text { Threshold } \\
\qquad \rho_{1}\end{array}$ & $\begin{array}{c}- \\
-0.06709 \\
(-2.071)\end{array}$ & $\begin{array}{c}0 \\
-0.115 * \\
(-2.557)\end{array}$ & $\begin{array}{c}0.404 \\
-0.149 \text { *** } \\
(-3.266)\end{array}$ & $\begin{array}{c}0 \\
-0.066 \\
(-1.378)\end{array}$ & $\begin{array}{c}-0.122 \\
-0.065 \# \\
(-1.655)\end{array}$ \\
\hline$\rho_{2}$ & - & $\begin{array}{c}-0.039 \\
(-0.813)\end{array}$ & $\begin{array}{l}-0.011 \\
(-0.24)\end{array}$ & $\begin{array}{l}-0.091 \text { * } \\
(-1.954)\end{array}$ & $\begin{array}{l}-0.112 * \\
(-1.814)\end{array}$ \\
\hline$\varphi_{1}$ & & $\begin{array}{l}0.327^{* * *} \\
(3.006)\end{array}$ & $\begin{array}{l}0.328^{* * *} \\
(3.078)\end{array}$ & $\begin{array}{l}0.316^{* * *} \\
(2.855)\end{array}$ & $\begin{array}{l}0.313^{* * *} \\
(2.835)\end{array}$ \\
\hline$\varphi_{2}$ & & $\begin{array}{c}0.181 \\
(1.626)\end{array}$ & $\begin{array}{l}0.203 * \\
(1.848)\end{array}$ & $\begin{array}{c}0.163 \\
(1.424)\end{array}$ & $\begin{array}{c}0.165 \\
(1.472)\end{array}$ \\
\hline \multicolumn{6}{|c|}{ Diagnostics } \\
\hline AIC & - & -22.288 & -25.691 & -20.97 & -21.252 \\
\hline $\mathrm{BIC}$ & - & -10.316 & -13.718 & -8.997 & -9.279 \\
\hline $\mathrm{R}^{2}$ & 0.2686 & 0.1998 & 0.2327 & 0.1867 & 0.1895 \\
\hline QLB(4) & 0.636 & 0.998 & 0.99 & 0.995 & 0.991 \\
\hline QLB(8) & 0.6807 & 0.946 & 0.872 & 0.943 & 0.936 \\
\hline QLB(12) & 0.8969 & 0.994 & 0.976 & 0.995 & 0.99 \\
\hline \multicolumn{6}{|c|}{ Hypotheses } \\
\hline$\Phi\left(H 0: \rho_{1}=\rho_{2}=0\right)$ & $\begin{array}{l}- \\
-\end{array}$ & $\begin{array}{c}3.541 \\
(0.03379 *)\end{array}$ & $\begin{array}{c}5.345 \\
\left(0.006706^{* *}\right)\end{array}$ & $\begin{array}{c}2.862 \\
(0.06323)\end{array}$ & $\begin{array}{c}3.007 \\
(0.0553)\end{array}$ \\
\hline $\mathrm{F}\left(H 0: \rho_{1}=\rho_{2}\right)$ & $\begin{array}{l}- \\
-\end{array}$ & $\begin{array}{c}1.397 \\
(0.241)\end{array}$ & $\begin{array}{c}4.76 \\
(0.032)\end{array}$ & $\begin{array}{c}0.131 \\
(0.718)\end{array}$ & $\begin{array}{c}0.401 \\
(0.529)\end{array}$ \\
\hline
\end{tabular}

Note: $p$-value $<0.001$, denoted as ${ }^{\star * * * \prime} ; p$-value $<0.01$, denoted as ${ }^{` * * \prime} ; p$-value $<0.05$, denoted as ${ }^{` * \prime} ; p$-value $<0.1$, denoted as ' $\#^{\prime}$. $p$-value in the brackets.

The point estimate of the consistent TVAR for the price adjustment was -0.149 when facing positive shocks and -0.011 when facing negative shocks. Therefore, the abovethreshold deviations $\left(\widehat{\varepsilon_{t-1}} \geq 0.404\right)$ take around 7 months $(1 / 0.149=6.71$ months $)$ to be fully adjusted to long-run equilibrium, while below-threshold deviations $\left(\widehat{\varepsilon_{\mathrm{t}-1}} \leq 0.404\right)$ take 91 months (almost 7.58 years) to return to equilibrium. Convergence for the abovethreshold deviations from the long-run equilibrium is faster than the below-threshold deviations. If there were negative deviations of price from long-run equilibrium, which may be an indication of a price increase in the Chinese market or price decrease in the global market, the adjustment of its global prices was very slow. If there were positive deviations such that the price in the Chinese market was decreasing or the price in the global market was increasing, the adjustment was faster. This is consistent with the results found by Acosta, et al. [40] that milk price fluctuations in global markets are transmitted to domestic markets in Panama at a lower magnitude and is asymmetric that the transmission speed is faster when there are increases in global prices than deceases.

Therefore, the global export price of New Zealand is subjected to the export price movements in the Chinese market, which could be explained by the large market share and New Zealand's SMP export dependence on the demand of China. New Zealand had put almost all its eggs (i.e., SMP export market share) in the same basket (i.e., China), thus the export market in the Chinese market is of vital importance to New Zealand. Therefore, the price changes or deviations from long-run equilibrium would greatly change the overall export prices of New Zealand, especially if there is a drop in the prices in the Chinese market. Although New Zealand has dominated the Chinese SMP imported market, the 
Chinese market, to a great degree, has vital deciding effects on the SMP export prices fluctuation of New Zealand.

For SMP New Zealand's export prices are much slower to adjust to equilibrium than Ireland's when there are shocks to the prices, regardless of negative or positive shocks. However, the estimated results in the four models were not substantially consistent and $\mathrm{R}^{2}$ results for all models were quite low. As the models in the case of New Zealand were not a good fit, the results may not be sufficiently reliable.

\subsubsection{Error Correction Model Results Analysis}

Table 6 outlines the results of the asymmetric error correction model with threshold cointegration for New Zealand's SMP export prices. It showed

Table 6. Results of the asymmetric error correction model with threshold cointegration for New Zealand.

\begin{tabular}{|c|c|c|c|c|}
\hline & \multicolumn{2}{|c|}{ New Zealand China } & \multicolumn{2}{|c|}{ New Zealand World } \\
\hline & Estimation & T-Ratio & Estimation & T-Ratio \\
\hline (Intercept) & 0.039 & 0.829 & 0.042 & 0.89 \\
\hline$\alpha_{i 1}^{+}$ & 0.155 & 0.624 & 0.016 & 0.066 \\
\hline$\alpha_{i 2}^{+}$ & -0.211 & -0.867 & 0.214 & 0.874 \\
\hline$\alpha_{\mathrm{i} 1}^{\frac{12}{2}}$ & 0.154 & 0.799 & -0.184 & -0.952 \\
\hline$\alpha_{\mathrm{i} 2}^{\frac{11}{2}}$ & 0.167 & 0.863 & 0.011 & 0.057 \\
\hline$\beta_{\mathrm{i} 1}^{+1}$ & -0.061 & -0.368 & 0.318 * & 1.902 \\
\hline$\beta_{\mathrm{i} 2}^{+1}$ & 0.036 & 0.201 & $0.267 \#$ & 1.504 \\
\hline$\beta_{\mathrm{i} 1}^{-\frac{12}{2}}$ & 0.123 & 0.453 & 0.372 & 1.366 \\
\hline$\beta_{\mathrm{i} 2}^{\frac{11}{2}}$ & -0.257 & -0.985 & 0.216 & 0.825 \\
\hline$\delta_{i}^{+12}$ & 0.033 & 0.47 & $-0.217^{* * *}$ & -3.045 \\
\hline$\delta_{i}^{-}$ & $0.142 * *$ & 2.385 & $0.114 *$ & 1.905 \\
\hline $\mathrm{R}^{2}$ & 0.164 & - & 0.268 & - \\
\hline AIC & -7.132 & - & -6.639 & - \\
\hline $\mathrm{BIC}$ & 21.602 & - & 22.094 & - \\
\hline QLB(4) & 0.602 & - & 0.963 & - \\
\hline QLB(8) & 0.790 & - & 0.683 & - \\
\hline F-statistics & \multicolumn{2}{|c|}{$1.372(0.2115)$} & \multicolumn{2}{|c|}{$2.559(0.01072)$} \\
\hline
\end{tabular}

New Zealand's own-country price transmission, which was fitted by an asymmetric error correction model with consistent TAR, does show some difference. There was only one coefficient $\delta_{\mathrm{cn}}^{-}$significant in the China equation, while there were four coefficients (i.e., $\beta_{\text {world } 1}^{+}, \beta_{\text {world2 }}^{+}, \delta_{\text {world }}^{+}, \delta_{\text {world }}^{-}$) significant at the level of $10 \%$ in the world equation. The $\mathrm{R}^{2}$ statistic was 0.164 for the China equation and 0.268 for the world equation, while the AIC and BIC statistics are lower for the China equation. The $F$ statistic for the overall fitness of the AECM-C-TAR model of China was 1.372, which was not significant at the level of $10 \%$, while the $F$ statistic for the world model was 2.559 , which shows that the model was appropriate at the level of $1 \%$ significance.

In the case of New Zealand's export to the world, the estimate for coefficients of the correction term was -0.217 for the positive error correction term $\delta_{\text {world }}^{+}$and was 0.114 for the negative error correction term $\delta_{\text {world }}^{-}$in the global market. It can be concluded that the adjustment path for the price in the global market was asymmetric when it faces positive and negative deviations in the case of New Zealand. In the short term, the SMP export price of New Zealand in the global market responds faster to positive deviations than negative deviations from the long-run equilibrium between global price and Chinese price.

In the China equation, the estimate for the coefficient of the positive error correction term $\delta_{\text {china }}^{+}$was 0.033 and was 0.142 for the coefficient of the negative term $\delta_{\text {china: Thus, }}^{-}$ in the short term, the adjustment of export prices to China converged to the long-run 
equilibrium at a much slower speed when there were positive deviations compared to negative deviations.

\section{Empirical Results of the Cross-Country Price Relationship in the Chinese Market}

In this section, the empirical results of the cross-country price transmission in the Chinese market are analysed. Table 7 outlines the results for the Engle-Granger and threshold cointegration tests based on Equations (2) and (3) in Section 3.1 for the IrelandNew Zealand price relationship in the Chinese Market. Both Equations (2) and (3) are based on the error of Equation (1) $Y_{t}=\alpha_{0}+\alpha_{1} X_{t}+\varepsilon_{t}$, where $X_{t}$ is the vector of New Zealand's export price in the Chinese market, $\mathrm{p}_{\mathrm{nz}}^{\mathrm{c}}$, and $\mathrm{Y}_{\mathrm{t}}$ is the vector of Ireland's export price in the Chinese market, $p_{\mathrm{ie}}^{\mathrm{c}}$.

Table 7. Results of Engle-Granger and threshold cointegration tests on SMP export prices of New Zealand and Ireland to China.

\begin{tabular}{|c|c|c|c|c|c|}
\hline Item & Engle-Granger & TAR & Consistent TAR & MTAR & Consistent MTAR \\
\hline \multicolumn{6}{|c|}{ Estimate } \\
\hline \multicolumn{6}{|c|}{ Long-run regression } \\
\hline Intercept & $\begin{array}{l}0.4331^{* *} \\
(2.258)\end{array}$ & $\begin{array}{l}0.4331 * * \\
(2.258)\end{array}$ & $\begin{array}{l}0.4331^{* *} \\
(2.258)\end{array}$ & $\begin{array}{l}0.4331^{* *} \\
(2.258)\end{array}$ & $\begin{array}{l}0.4331^{* *} \\
(2.258)\end{array}$ \\
\hline Export price to China, $\mathrm{p}_{\mathrm{nz}}^{\mathrm{c}}$ & $\begin{array}{c}0.9034^{* * *} \\
(15.666)\end{array}$ & $\begin{array}{c}0.9034^{* * *} \\
(15.666)\end{array}$ & $\begin{array}{c}0.9034^{* * *} \\
(15.666)\end{array}$ & $\begin{array}{c}0.9034^{* * *} \\
(15.666)\end{array}$ & $\begin{array}{c}0.9034^{* * *} \\
(15.666)\end{array}$ \\
\hline Threshold & - & 0 & -0.432 & 0 & -0.005 \\
\hline$\rho_{1}$ & $\begin{array}{l}-0.8538 \\
(-5.894)\end{array}$ & $\begin{array}{l}-0.82^{* * *} \\
(-6.155)\end{array}$ & $\begin{array}{l}-0.799 * * * \\
(-6.406)\end{array}$ & $\begin{array}{l}-0.951 * * * \\
(-7.406)\end{array}$ & $\begin{array}{l}-0.951^{* * *} \\
(-7.415)\end{array}$ \\
\hline$\rho_{2}$ & - & $\begin{array}{c}-0.821 * * * \\
(-4.262)\end{array}$ & $\begin{array}{l}-0.893^{* * *} \\
(-3.902)\end{array}$ & $\begin{array}{l}-0.492^{* *} \\
(-2.446)\end{array}$ & $\begin{array}{l}-0.49^{* *} \\
(-2.425)\end{array}$ \\
\hline$\varphi_{1}$ & $\begin{array}{l}0.0425 \\
(0.378)\end{array}$ & & & & \\
\hline \multicolumn{6}{|c|}{ Diagnostics } \\
\hline $\mathrm{AIC}$ & - & 103.358 & 103.225 & 99.443 & 99.426 \\
\hline $\mathrm{BIC}$ & - & 110.614 & 110.482 & 106.663 & 106.646 \\
\hline $\mathrm{R}^{2}$ & 0.7496 & 0.409 & 0.4099 & 0.4319 & 0.4321 \\
\hline QLB(4) & 0.9994 & 0.989 & 0.994 & 0.784 & 0.792 \\
\hline QLB(8) & 0.7253 & 0.688 & 0.72 & 0.472 & 0.472 \\
\hline QLB(12) & 0.9246 & 0.906 & 0.919 & 0.731 & 0.734 \\
\hline \multicolumn{6}{|c|}{ Hypothesis } \\
\hline$\left.\Phi\left(H 0: \rho_{1}=\right] \rho_{2}=0\right)$ & $\begin{array}{l}- \\
-\end{array}$ & $\begin{array}{c}28.024 \\
\left(<0.001^{* * *}\right)\end{array}$ & $\begin{array}{c}28.133 \\
\left(<0.001^{* * *}\right)\end{array}$ & $\begin{array}{c}30.415 \\
\left(<0.001^{* * *}\right)\end{array}$ & $\begin{array}{c}30.429 \\
\left(<0.001^{* * *}\right)\end{array}$ \\
\hline $\mathrm{F}\left(H 0: \rho_{1}=\rho_{2}\right)$ & - & $\begin{array}{c}0 \\
(0.997)\end{array}$ & $\begin{array}{l}0.129 \\
(0.72)\end{array}$ & $\begin{array}{c}3.688 \\
(0.058)\end{array}$ & $\begin{array}{c}3.705 \\
(0.058)\end{array}$ \\
\hline
\end{tabular}

Note: $p$-value $<0.001$, denoted as ${ }^{` * * * \prime} ; p$-value $<0.01$, denoted as ${ }^{\prime * * \prime} ; p$-value $<0.05$, denoted as ${ }^{\prime * \prime} ; p$-value $<0.1$, denoted as ' $\# \prime^{\prime}$. $p$-value in the brackets.

\subsection{Engle-Granger Cointegration Analysis for New Zealand-Ireland Export Price Relationship}

The linear relationship of export prices of Ireland and New Zealand to China was estimated. The coefficient was 0.9034 which was significant at the level of $1 \%$. The relationship was shown in Equation (12). The result for the ADF test was -0.8538, implying that the hypothesis for stationarity was rejected at the significance level of $1 \%$. Therefore, the export prices of New Zealand and Ireland are cointegrated and the long-run regression relationship is as Equation (12).

$$
\mathrm{p}_{\mathrm{ie}}^{\mathrm{c}}=\begin{gathered}
0.4331 \\
(0.0266)
\end{gathered}+\underset{\left(<2 * 10^{-16}\right)}{0.9034} \mathrm{p}_{\mathrm{nz}}^{\mathrm{c}}+\varepsilon_{\mathrm{t}}
$$




\subsection{Non-Linear Threshold Cointegration Analysis for New Zealand-Ireland Export Price Relationship}

The nonlinear cointegration is also estimated using the above mentioned four threshold models. Different lags ranging from 1 to 12 were performed to select the best lag. According to the AIC statistics, the best lag for the models was 0 .

In the relationship of export prices of New Zealand and Ireland in the Chinese market, the consistent MTAR is the best fit with the lowest AIC and BIC statistics for the four models. Focusing on the results of consistent MTAR estimation, the hypothesis of symmetric adjustment can be rejected at the $10 \%$ significance level. Moreover, the two prices have a cointegrating relationship because no cointegration hypothesis can be rejected at the significance level of $1 \%$. The estimates of coefficients of adjustments to positive and negative shocks are -0.951 and -0.49 respectively. Both estimates are significant at the level of $5 \%$. Therefore, the above-threshold deviations from long-run equilibrium due to increases in Irish prices or decreases in New Zealand's prices could be corrected at a rate of $95.1 \%$ per month, while below-threshold deviations due to decreases in Irish prices or increases in New Zealand's prices could be corrected at a rate of $49 \%$ per month. In the long-term, the convergence for above-threshold deviations is very fast requiring only one month to return to long-run equilibrium, while it would take two months for below-threshold deviations to converge to long-run equilibrium. Therefore, the SMP export of two geographically separated countries are well integrated, and the adjustments of price changes are rapid yet a bit asymmetric. This is consistent with the conclusion of studies several studies where a strong and an increasing degree of overall price co-movement and statistically significant probabilities for joint price crashes and booms were found in the international SMP market, with the EU and Oceania have been the regions with the highest degree of integration [24]; and the dominant pattern of transmission of skim milk powder, in the long run, is asymmetric involving positive price stocks to be transmitted with higher intensity compared to negative prices shocks [30].

New Zealand has been the price leader in the Chinese SMP import market, and Irish export prices respond more rapidly to decreases than to increases in New Zealand's export prices. The reason behind the asymmetric price adjustment could be that New Zealand has been dominating China's SMP import market and has obtained a large SMP market share in China. Ireland, as a small player with no price advantage in China's SMP import market, could be greatly constrained by the price pressure from New Zealand. Ireland is forced to reduce its price quickly when New Zealand prices decrease and are unable to keep up with increases New Zealand's export prices in the Chinese market, implying that Irish SMP may lack competitiveness in terms of price due to the homogeneous attributes of SMP as a commodity. Additionally, Irish exporters' lack of tracking the price movement of New Zealand's export prices and a clear understanding of the price relationship between the export prices of New Zealand and Ireland in the Chinese market might explain the inferior position of Irish SMP export prices as well.

\subsection{Error Correction Model Results Analysis}

The consistent MTAR model was the best fit for export price relationship between New Zealand and Ireland. The estimated results of the asymmetric error correction model with consistent MTAR are reported in Table 8.

In the ECM-C-MTAR estimations, two coefficients (i.e., $\alpha_{\mathrm{nz}}^{-}$and $\delta_{\mathrm{nz}}^{+}$) were significant at the level of $10 \%$ for the New Zealand price equation, and two coefficients (i.e., $\delta_{\text {ie }}^{+}$and $\left.\delta_{\mathrm{ie}}^{-}\right)$were significant at the significance level of $1 \%$ for the Ireland price equation. Moreover, the squared $R$ statistic was only 0.1 for the New Zealand equation and 0.472 for the Ireland equation. The $F$ statistics of the model fitness were 1.392 and 11.19 for New Zealand and Ireland equations, respectively. The AIC and BIC statistics of the New Zealand equation are much lower than those for Ireland. To sum up, the AECM-C-MTAR fits better for Ireland.

The coefficients of the error correction term $\delta_{\text {ie }}^{+}$and $\delta_{\text {ie }}^{-}$in the equation of Ireland were significant for positive and negative deviations, and the point estimations are -1.09 
and -0.596 , respectively. Thus, it could be concluded that the price of Ireland adjusts faster to positive than negative deviations from long-run equilibrium in the short run. In the equation of New Zealand, the point estimate for the coefficient of the positive error correction term $\delta_{\mathrm{nz}}^{+}$is 0.208 and is significant at the level of $5 \%$. The point estimate of the negative error correction term $\delta_{\mathrm{nz}}^{+}$was 0.02 but was not significant at the $10 \%$ level. It could still be concluded that the price of New Zealand converges faster to long-run equilibrium for positive deviations in the short run.

Table 8. Results of the asymmetric error correction model with consistent MTAR.

\begin{tabular}{ccccc}
\hline & \multicolumn{2}{c}{ New Zealand } & \multicolumn{2}{c}{ Ireland } \\
\cline { 2 - 5 } & Estimation & T-Ratio & Estimation & T-Ratio \\
\hline (Intercept) & 0.02 & 0.472 & -0.016 & -0.206 \\
$\alpha_{i}^{+}$ & 0.128 & 0.545 & -0.141 & -0.321 \\
$\alpha_{i}^{-}$ & $0.465^{* *}$ & 2.314 & -0.39 & -1.038 \\
$\beta_{i}^{+}$ & -0.108 & -0.946 & 0.151 & 0.712 \\
$\beta_{i}^{-}$ & 0 & 0.002 & -0.02 & -0.133 \\
$\delta_{i}^{+}$ & $0.208^{*}$ & 1.674 & $-1.09 * * *$ & -4.693 \\
$\delta_{i}^{+}$ & 0.02 & 0.168 & $-0.596 * * *$ & -2.654 \\
$\mathrm{R}^{2}$ & 0.100 & - & 0.472 & - \\
AIB & -10.192 & - & 92.412 & - \\
BIC & 9.062 & - & 111.666 & - \\
QLB(4) & 0.198 & - & 0.947 & - \\
QLB(8) & 0.478 & - & 0.326 & $11.19(<0.001)$ \\
F-statistics & \multicolumn{2}{c}{$1.392(0.2291)$} & & \multicolumn{2}{c}{ - }
\end{tabular}

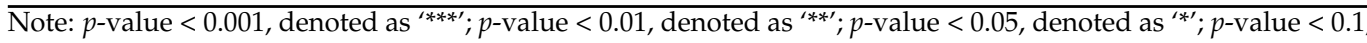
denoted as '\#'. $p$-value in the brackets.

\section{Discussions}

The export of skim milk powder is of vital importance to both New Zealand and Ireland, although in comparison, the SMP export volumes and values differ greatly. New Zealand has dominated Chinese imports SMP over the past decade thanks to its large production scale, early access to the Chinese market, superior trade policies and a strong brand image based on the country of origin of milk and dairy products. Nevertheless, the boom in imported milk powder has threatened the domestic dairy industry in China which triggers some ongoing negotiation on new cooperation modes and policies (such as multinational cooperation of domestic "star" dairy brands, increasing taxes on online imported products, stricter labelling requirements, etc.) between domestic milk powder brands and foreign exporters.

Several potential directions might be interesting for future research. Firstly, advanced models such as the global vector autoregressive model can be implemented to conduct the spatial price transmission of dairy products with other influential factors (e.g., exchange rate, energy prices, upstream raw material prices, policy changes, etc.) to addresses the complexity and dynamics of dairy export markets following market shocks. Secondly, export prices of different dairy products from different dairy export countries can be incorporate into analysis to figure out the interlinkage of products and global market integration. Thirdly, a well-designed theoretical model with mathematic deviations to reflect the variable causal relationship might be considered and incorporated into time series models in the future.

Several limitations need to be addressed. Firstly, this paper only analyses the export prices of SMP for New Zealand and Ireland, it would be better if the other comparable countries in the EU, such as Denmark, Germany and France are also put into the analysis with Ireland and New Zealand, to improve the understanding of market competition and entry barriers in the Chinese market. Secondly, limitations in economic theoretical supports and rigorous economic analysis probably weaken the economic implications of this study. 
Thirdly, time spans should be expanded to study whether the conclusions can be consistent with different time spans applied.

\section{Conclusions}

In this study, the price dynamics of Ireland and New Zealand, including three price transmission relationships, were explored, and several meaningful conclusions are drawn from this research.

(1) The asymmetries exist in the price transmission of the three price pairs, namely, export prices of Ireland in the world and the Chinese markets, export prices of New Zealand in the world and the Chinese markets and export prices of New Zealand and Ireland in the Chinese market, though displayed in different patterns. This is consistent with the previous studies on asymmetries of SMP price transmissions that the dominant pattern of transmission of SMP, in the long run, is asymmetric involving positive price stocks to be transmitted with higher intensity compared to negative prices shocks [30].

(2) In the long term, the SMP export of two geographically separated countries in the Chinese market are well integrated as the adjustments of price changes are rapid. New Zealand has been the price leader in the Chinese SMP imported market, and the export prices of Ireland responds more rapidly to decreases than to increases of the export prices of New Zealand. This is consistent with the trade pattern of the two countries and the conclusions of positive asymmetry found in the majority of spatial price studies [41], also consistent with other studies on price leadership that show dominated players in a market usually plays as price leaders [42].

(3) The threshold cointegration analysis reveals that in the long-term positive deviations of the price spread between prices of the Chinese market and the global markets take lesser time to be fully digested than negative deviations for Ireland, yet takes longer time to be fully digested than negative deviations for New Zealand. Similarly, in the short term, the error correction model reveals the price adjustment paths in the global market for both Ireland and New Zealand were asymmetric. So, for owncountry price transmission, Ireland and New Zealand displays opposite asymmetry directions. This can be explained by a previous study by Abdulai [27] that prices in local markets respond more rapidly to price increases in the central market. New Zealand mainly exports its SMP to the Chinese market, the Chinese market can be regarded as the central market for New Zealand. Ireland's SMP export destinations are more diversified, so there is no central market for Ireland.

Therefore, this study has several policy implications for international dairy trade patterns and for new entrants and small players to expand their share in the Chinese market. Dairy exporting countries that aim to expand market share in the Chinese market should explore new selling points and cooperation modes to turn the challenges into new opportunities to expand the scale of SMP exports to China, and market returns. The following advice is proposed: (1) Instead of competing directly in the SMP export with New Zealand in the Chinese market, Ireland or other similar new entrants to the Chinese dairy market should focus more on high value-added and high-end products, such as infant milk formula, sports nutritious products and packaged dairy products. (2) It is necessary to closer cooperation with Chinese companies to provide ingredients to China's domestic dairy producing companies to expand market share. (3) New entrants should continue to build the image for its sustainable, high-end and unique dairy sector in the Chinese market to create differentiation to its dairy products. (4) The export price of New Zealand could be an effective price signal for Ireland and other SMP exporting countries to adjust its SMP price and export pattern in advance.

Author Contributions: Conceptualization, H.X., C.L. and L.W.; methodology, H.X.; software, H.X.; validation, H.X.; formal analysis, H.X.; investigation, H.X.; resources, H.X.; data curation, H.X.; writing-original draft preparation, H.X.; writing—review and editing, H.X., C.L. and L.W.; visualiza- 
tion, H.X.; supervision, C.L. and L.W.; project administration, H.X., C.L. and L.W.; funding acquisition, H.X. and L.W. All authors have read and agreed to the published version of the manuscript.

Funding: This research was funded by the UCD-CSC Scholarship Scheme supported by University College Dublin (UCD) and China Scholarship Council (CSC).

Institutional Review Board Statement: Not applicable.

Conflicts of Interest: The authors declare no conflict of interest.

\section{References}

1. DAFM. Food Wise 2025: A 10-Year Vision for the Irish Agri-Food Industry; Department of Agriculture, Food and the Marine: Dublin, Ireland, 2015.

2. European-Commission. Prospects for EU Agricultural Markets and Income 2014-2014; European Commission: Brussels, Belgium, 2014.

3. Fuller, F.; Beghin, J.; Rozelle, S. Consumption of dairy products in urban China: Results from Beijing, Shangai and Guangzhou. Aust. J. Agric. Resour. Econ. 2007, 51, 459-474. [CrossRef]

4. He, Y.; Yang, X.; Xia, J.; Zhao, L.; Yang, Y. Consumption of meat and dairy products in China: A review. Proc. Nutr. Soc. 2016, 75, 385-391. [CrossRef] [PubMed]

5. Rae, A.N. Changing food consumption patterns in East Asia: Implications of the trend towards livestock products. Agribusiness 1997, 13, 33-44. [CrossRef]

6. Rutherford, A.S. Meat and milk self-sufficiency in Asia: Forecast trends and implications. Agric. Econ. 1999, 21, 21-39.

7. Shono, C.; Suzuki, N.; Kaiser, H.M. Will China's diet follow western diets? Agribusiness 2000, 16, 271-279. [CrossRef]

8. Zhou, Y.; Wang, E. Urban consumers' attitudes towards the safety of milk powder after the melamine scandal in 2008 and the factors influencing the attitudes. China Agric. Econ. Rev. 2011, 3, 101-111. [CrossRef]

9. NZIER. QuickStats about Dairying - NEW ZEALAND; New Zealand Institute of Economic Research: Wellington, New Zealand, 2014. Available online: https:/ / www.dairynz.co.nz/media/5794072/quickstats-about-dairying-new-zealand-2020-web.pdf (accessed on 25 April 2021).

10. Jongeneel, R.; Van Berkum, S.; de Bont, C.; Van Bruchem, C.; Helming, J.; Jager, J. European Dairy Policy in the Years to Come; Quota Abolition and Competitiveness; 9086154190; LEI Wageningen UR: Hague, The Netherlands, 2010.

11. Asensio, L.; González, I.; García, T.; Martín, R. Determination of food authenticity by enzyme-linked immunosorbent assay (ELISA). Food Control 2008, 19, 1-8. [CrossRef]

12. Fackler, P.; Goodwin, B. Spatial price analysis. In Handbook of Agricultural Economics; Gardner, B.L., Rausser, G.C., Eds.; Elsevier: Amsterdam, The Netherlands, 2001; Volume 1, Part 2; pp. 971-1024.

13. Meyer, J.; von Cramon-Taubadel, S. Asymmetric Price Transmission: A Survey. J. Agric. Econ. 2004, 55, 581-611. [CrossRef]

14. Bord-Bia. Export Performance and Prospects: Irish Food, Drink and Horticulture 2017-2018; Bord Bia: Dublin, Ireland, 2018.

15. FAO; OECD. OECD-FAO Agricultural Outlook 2015-2024; OECD Publishing: Paris, France, 2015.

16. Keane, M.; O'Connor, D. Price Volatility in the EU dairy Industry: Causes, Consequences and Coping Mechanisms; University of Cork report prepared for the European Dairy Association; Cork Institute of Technology: Cork, Ireland, 2009.

17. Phlips, L. Common markets: Towards a theory of market integration. J. Ind. Econ. 1962, 10, 81-92. [CrossRef]

18. Elizabeth Gooch, R.H.; Law, J. China Dairy Supply and Demand; USDA: Washington, DC, USA, 2017.

19. Wang, J. Opportunities and Challenges of International e-Commerce in the Pilot Areas of China. Int. J. Mark. Stud. 2014, 6, 141. [CrossRef]

20. Jia, X.; Huang, J.; Luan, H.; Rozelle, S.; Swinnen, J. China's Milk Scandal, government policy and production decisions of dairy farmers: The case of Greater Beijing. Food Policy 2012, 37, 390-400. [CrossRef]

21. Pei, X.; Tandon, A.; Alldrick, A.; Giorgi, L.; Huang, W.; Yang, R. The China melamine milk scandal and its implications for food safety regulation. Food Policy 2011, 36, 412-420. [CrossRef]

22. Ballingall, J.; Pambudi, D. Dairy Trade's Economic Contribution to New Zealand; New Zealand Institute of Economic Research: Wellington, New Zealand, 2017.

23. DCANZ. About the NZ Dairy Industry; Dairy Companies Association of New Zealand: Wellington, New Zealand, 2018.

24. Fousekis, P.; Emmanouilides, C.; Grigoriadis, V. Price linkages in the international skim milk powder market: Empirical evidence from nonparametric and time-varying copulas. Aust. J. Agric. Resour. Econ. 2017, 61, 135-153. [CrossRef]

25. Fousekis, P.; Grigoriadis, V. Joint price dynamics of quality differentiated commodities: Copula evidence from coffee varieties. Eur. Rev. Agric. Econ. 2017, 44, 337-358. [CrossRef]

26. Goodwin, B.K.; Piggott, N.E. Spatial Market Integration in the Presence of Threshold Effects. Am. J. Agric. Econ. 2001, 83, 302-317. [CrossRef]

27. Abdulai, A. Spatial price transmission and asymmetry in the Ghanaian maize market. J. Dev. Econ. 2000, 63, 327-349. [CrossRef]

28. Listorti, G.; Esposti, R. Horizontal price transmission in agricultural markets: Fundamental concepts and open empirical issues. Bio-Based Appl. Econ. 2012, 1, 81-108. 
29. Serra, T.; Gil, J.M.; Goodwin, B.K. Local polynomial fitting and spatial price relationships: Price transmission in EU pork markets. Eur. Rev. Agric. Econ. 2006, 33, 415-436. [CrossRef]

30. Fousekis, P.; Trachanas, E. Price transmission in the international skim milk powder markets. Appl. Econ. 2016, 48, 5233-5245. [CrossRef]

31. Enders, W.; Siklos, P.L. Cointegration and Threshold Adjustment. J. Bus. Econ. Stat. 2001, 19, 166-176. [CrossRef]

32. Engle, R.F.; Granger, C.W.J. Co-Integration and Error Correction: Representation, Estimation, and Testing. Econometrica 1987, 55, 251-276. [CrossRef]

33. Tong, H. Threshold Models in Non-Linear Time Series Analysis; Springer: New York, NY, USA, 1983; Volume 21.

34. Dickey, D.A.; Fuller, W.A. Distribution of the Estimators for Autoregressive Time Series with a Unit Root. J. Am. Stat. Assoc. 1979, $74,427-431$.

35. Enders, W.; Granger, C.W.J. Unit-Root Tests and Asymmetric Adjustment with an Example Using the Term Structure of Interest Rates. Source J. Bus. Econ. Stat. 1998, 1643120, 304-311.

36. Sun, C. R Package: Apt. 2016. Available online: https://cran.r-project.org/web/packages/apt/index.html (accessed on 25 April 2021).

37. Bord-Bia. Export Performance and Prospects: Irish Food, Drink and Horticulture 2013-2014; Bord Bia: Dublin, Ireland, 2014.

38. Bord-Bia. Export Performance and Prospects: Irish Food, Drink and Horticulture 2014-2015; Bord Bia: Dublin, Ireland, 2015.

39. Chan, K.S. Consistency and Limiting Distribution of the Least Squares Estimator of a Threshold Autoregressive Model. Ann. Stat. 1993, 21, 520-533. [CrossRef]

40. Acosta, A.; Thle, R.; Robles, M. Spatial Price Transmission of Soaring Milk Prices From Global to Domestic Markets. Agribusiness 2014, 30, 64-73. [CrossRef]

41. Frey, G.; Manera, M. Econometric models of asymmetric price transmission. J. Econ. Surv. 2007, 21, 349-415. [CrossRef]

42. Sun, C. Price dynamics in the import wooden bed market of the United States. For. Policy Econ. 2011, 13, 479-487. [CrossRef] 